\title{
Dido and Aeneas: An Archetypical Myth at the Roots of the Cultural Dialogue between the Two Shores of the Mediterranean
}

\author{
Maria Nicole lulietto \\ University of Perugia
}

\begin{abstract}
The aim of this paper is to examine the famous Virgilian myth of Dido, queen of Carthage, and Aeneas, the legendary ancestor of Rome, as an archetype of the cultural dialogue between different Mediterranean cultures. Not only will this allow us to underline the preeminent role of the classical heritage in the construction of the European identity, but also to demonstrate how this ancient legend, dealing with very current topic such as interculturality, immigration and hospitality - which appear, on a lexical level, in the insistence on such terms as sociare, miscere, iungere in the first (as well as in the fourth) book of the Aeneid - should be still deserving attention by scholars and European citizens in general.
\end{abstract}

Keywords: Interculturality, Classics, Myth, Aeneid, Identity, Mediterranean cultures

\section{Introduction}

The story of Dido, queen of Carthage, and Aeneas, the legendary ancestor of Rome, is not only a myth of love, abandonment and death. The famous story told in Virgil's Aeneid is actually one of the foundative myths of our Western identity, whose archetypal values deserve to be rediscovered and duly valued. This ancient legend, in particular, could be read as an archetype of the cultural dialogue between different Mediterranean cultures, as it deals with present-day issues such as interculturality, immigration and hospitality. In this regard, Virgil develops an interesting dialogue between the main characters in the first book of the Aeneid, which can be read with a particular focus on the topic of alteritas and acceptance of diversity. In the following pages, therefore, I will provide an 'actualized' reinterpretation of the poem, by analyzing Virgil's insistence on the specific lexicon of cooperation and solidarity'.

As is known, in Virgil's account the Trojan leader Aeneas was shipwrecked on the shore near Carthage after the destruction of Troy, at the time when Dido, the Phoenician princess who had been forced to leave her original country and flee to the coast of Africa, was building the city that would later become one of the powerful centers of the western Mediterranean. In this part of the story, Aeneas is presented as the emblem of the lonely and distressed man, standing for all those migrants and refugees of war, who hoped - and still hope - to be able to start again elsewhere. This is indeed the meaningful sentence that Virgil makes him pronounce, which is even more so as Aeneas is one of the greatest epic heroes: ipse ignotus egens Libyae deserta peragro, I Europa atque Asia pulsus... "Myself unknown and destitute, I wander over the Libyan wastes, driven from Europe and from Asia" $(1,384-385)^{2}$. After the fall of Troy, the whole world refuses Aeneas even Asia, his own land. It didn't matter who he was or had been. Even the son of a goddess could find himself in such a miserable condition.

Dido, on the other hand, was then the queen of a flourishing kingdom, the only one who could offer help to the Trojan refugees escaping the terrible shipwreck that had caused the deaths of many of them. Moreover, she was, per se, an example of a successful integration, being a Tyrian princess who had fled from her native country, from the tyranny of her brother Pygmalion who had killed her husband for greed, and having succeeded in securing herself a position in a foreign land before founding a new city on the coast of Africa. Carthage is described as a city still under construction, but destined

\footnotetext{
1 On the Virgilian myth of Dido and Aeneas the bibliography is extensive. For a general overview on the 'stories' of Dido and their related bibliography, see lulietto 2014; lulietto 2015 et alii.

${ }^{2}$ As for the Latin original text, I refer to Conte 2009. The English translations are from Rushton Fairclough 1999.
} 
to a grand future; a place where justice and civilization reigned $(1,421-436)$ and whose queen was going to give a lesson in civility to the Trojans (and all the readers, ancient and modern, of Virgil).

At I. 507 the queen is intent in dictating her laws to her subjects and directing the works of construction. Hesitant and fearful, the Trojans decide to remain hidden at first, until one of them, llioneus, takes courage and becomes the spokesman of his fellows, asking to be welcomed and helped. In a long speech (1, 522-558), llioneus presents the Trojans as exiles arrived in that land not to destroy but as themselves defeated (victi) by a cruel fate that made them shipwreck (non nos aut ferro Libycos populare penatis / venimus aut raptas ad litora vertere praedas; I non ea vis animo nec tanta superbia victis, "we have not come to spoil with the sword your Lybian homes or to drive stolen booty to the shore. No such violence is in our hearts, nor have the vanquished such assurance", 1, 527-529). Then, llioneus accuses the Carthaginians of having previously denied the refuge on the beach to other men in need (although there is no reference to such episode in Virgil), thus blaming their barbarism: quod genus hoc hominum? quaeve hunc tam barbara morem / permittit patria? hospitio prohibemur harenae; / bella cient primaque vetant consistere terra, "what race of men is this? What land is so barbarous as to allow this costum? We are debarred the welcome of the beach; they stir up wars and forbid us to set foot on the border of their land" $(1,539-541)$. Those who behave like this, llioneus remarks, have contempt for the whole human race $(1,542)$. In this regard, according to the ancient legal practice, as both Servius and Servius Danielinus - two famous ancient commentators of Virgil - point out in reference to this passage, seashores were actually considered "goods" common to all men ${ }^{1}$. For this reason, llioneus concludes his oration with an appeal to humanitas and divine justice and with a request of hospitium - a term probably indicating the earliest example of an international relationship ${ }^{2}$, so that the Trojans could rebuild their fleet and resume their journey, to Italy if Aeneas lives, to Sicily if he is dead $(1,551-558)$.

Dido's magnanimous response astonishes us for political foresight and straightforwardness. After apologizing for the precautionary measures she had had to take (the res dura and the regni novitas imposed to control the borders on a sensible queen $)^{3}$, Dido proudly states that her city is founded on justice and that they will offer help and means to the refugees. The demonstration of the high civilisation of her people is reinforced with a further proposal: she proves willing to help Aeneas and his men, not only out of mere hospitality but also because she evidently hopes for a possible cultural integration. As a matter of fact, she allows them to settle down in Carthage and enjoy the same rights as the Tyrians, thus overcoming any ethnic difference or partiality:

auxilio tutos dimittam opibusque iuvabo.

vultis et his mecum pariter considere regnis:

urbem quam statuo, vestra est; subducite navis;

Tros Tyriusque mihi nullo discrimine agetur 4 .

$(1,571-574)$

\footnotetext{
1 See Serv. ad Aen. 540: "HOSPITIO PROHIBEMUR HARENAE ut alibi litusque rogamus; occupantis est enim possessio litoris. unde ostenduntur crudeles qui etiam a communibus prohibeant". Servius Danielinus, ad loc., quotes Cicero's oratio Pro Roscio Amerino 26, 72: "litus enim iure gentium commune omnibus fuit et occupantis solebat eius esse possessio. Cicero in Rosciana nam quid est tam commune quam spiritus vivis, terra mortuis, mare fluctuantibus, litus eiectis?". Among the goods common to all men, Cicero mentions the air for the living, the land for the dead, the sea for the shipwrecked and the seashore for those who were repulsed by the waves. On the legal issue of the litus maris as res communis see, for instance, Fiorentini 2003 and Sini 2008.

2 Hospitium and hospes are key-words in a "poema come l'Eneide incentrato sul motivo delle peregrinazioni e del viaggio e poi sul sistema di alleanze che prelude alla guerra nel Lazio" (Degl'Innocenti Pierini 1985, p. 860). According to Virgilian exegesis the term hospitium (attested 14 times in the Aeneid) originally designated the act by which the foreigner was welcome and protected, and then came to indicate the reciprocal bond resulting from the act itself (see, for instance, Serv. Dan. ad Aen. 11, 114).

${ }_{3}^{3}$ Dido refers to the miserable situation from which she escaped (the murder of her husband by Pygmalion and the escape from Tyre) and to the dangerous hostility of the neighbouring peoples of Lybia (Stégen 1975, p. 257).

4 "I will send you hence guarded by an escort, and aid you with my wealth. Or is it your wish to settle with me on even terms within these realms? The city I build is yours; draw up your ships; Trojan adn Tyrian I shall treat alike". It should be noted that Dido offers donatives to her hospites (1,633 ff.), following the practice of hospitium publicum, thus concretely showing the high degree of civilization of her people (Degl'Innocenti Pierini 1985, p. 860).
} 
It is only at this point that Aeneas, reassured, reveals himself to Dido (he had remained invisible while the Trojans pleaded for the mercy of the queen and implored her help). With a heartfelt prayer, the hero thanks the queen for having associated them, exhausted and needy as they were, to the city and her kingdom (urbe, domo socias):

o sola infandos Troiae miserata labores,

quae nos, reliquias Danaum, terraeque marisque

omnibus exhaustos iam casibus, omnium egenos,

urbe, domo socias, grates persolvere dignas

non opis est nostrae, Dido...1

$(1,597-601)$

Dido concludes their conversation by reaffirming ${ }^{2}$ and further developping his proposal for integration. This evidently stems from her profound sense of solidarity, which is the result of her past experience ${ }^{3}$. In other words, Dido proves that she has not forgotten her past as an exile and fugitive herself; on the contrary, she has learned to be empathetic and well-disposed to accepting others. As mentioned above, she had to flee from her homeland in search for a new land, where she could start anew $(1,628-630)$. This is indeed the common fate that binds her to Aeneas, and that she does not overlook: Non ignara mali miseris succurere disco, "Not ignorant of ill I learn to aid distress" $(1,630)$. Anyone who knows and understands pain, the queen thus teaches, should learn to help those in need.

The hypothesis envisaged by Dido - responding to the criteria of justice (iustitia) and conscience of the good (mens sibi conscia recti, 1, 604) - is defined in terms of a political cooperation based on the intercultural dialogue and on the integration between the two peoples. Her proposal is significantly defined through the repeated use of the lexicon of solidarity (iuvare, succurrere, auxilium, hospitium) and of terms proper to the semantic sphere of the union (sociare, miscere, iungere).

In this regard, Virgil begins to draw on this semantic area even before Dido's mentioned proposal, in order to anticipate narratologically the yearning for this ethnic fusion, with his recourse to the allusive prolepsis arisen from the amphibological use of these terms ${ }^{4}$. When Aeneas enters the city, silent and frightened, veiled in a foggy cloud that protects him, for instance, the poet says that the hero manages to mingle with the crowd (miscetque viris, 1, 440), without anyone noticing. Virgil uses the verb misceo, technically indicating the effect of the blending of various substances, especially liquids, to indicate the fusion of peoples from which a foedus could originate. In this regard, I. 440 seems to anticipate the idea of the blending of the Carthaginians and the Trojans evoked by Venus in 4, 112 (miscerive probet populos aut foedera iungi) ${ }^{5}$.

Similarly, the expression iungere dextram, which properly concerns the settling of a foedus and defines, in Virgil, the agreement between the parties in a pact of hospitium ${ }^{6}$, is used for the first time when Aeneas, just landed in Carthage, met his mother Venus in disguise. When he finally acknowledges her as his mother, he regrets not being able to clasp hands with her, nor being able to establish a real and authentic contact (dextrae iungere dextram, 1, 408). In this case the formulation is refunctionalized in a sentimental way, to indicate Aeneas's yearning to be welcome, in a moment of extreme solitude, when he feels rejected by everyone.

\footnotetext{
1 "O you who alone have pitied Troy's unutterable woes, you who grant us - the remnant left by the Greeks, now outworn by every mischance of land and sea, and destitute of all - a share in your city and home, to pay you fitting thanks, Dido, is not in our power...". 2 See Serv. ad Aen. 1, 627: "TECTIS SUCCEDITE NOSTRIS ad convivium vocat; nam iam supra dixit urbe, domo socias".

${ }^{3}$ Note that both Aeneas and Dido are qualified as wanderers: profectus is Aeneas with his fellows $(4,111)$; profecta, / Germanum fugiens is Dido (1, 340-341), also defined errans by larbas $(4,211)$.

${ }^{4}$ Servius too remarks, moreover, that Virgil makes use of terms that act as proleptic elements of the narration; see ad Aen. 1,613: "OBSTIPUIT animo perculsa est, quo iam futuri amoris est signum".

${ }^{5}$ Senis 1987, p. 541. The same verb will be also used later in reference to the fusion of Teucri and Latini (Teucri mixtique... Latini, 11, 134).

${ }^{6}$ Virgil shares the opinion that the sanction of the agreement between the parties in a pact of hospitality had to be defined by a hand shake, so as to underline the fides on which the relationship was being built. This is how the renewed pact of friendship between Anius, king of Delus, and Anchises is sanctioned (iungimus hospitio dextras, 3, 83). Evandrus too recalls the pact he had made with Aeneas with the same formula (nec quas / iunximus hospitio dextras, 11, 164-165). See Degl'Innocenti Pierini 1985, p. 861.
} 
This same expression, with a slight variation, is also used a little below. At the sight of Dido, sitting royally while imparting her laws, the Trojans eagerly wish to clasp their hands (avidi coniungere dextras / ardebant, 1, 514) with the Carthaginians. In this context, the expression is used in a properly political sense, which however does not elide the broader idea of the union as foundation of an authentic relationship, be it private or political.

Moreover, this formula could also allusively anticipate the theme of coniugium (a noun that shares the same root as iungo), which is in Book IV of the Aeneid. In fact, the amphibological use of such lexicon becomes a tool to show the inevitable sliding of Dido's political project on a private and sentimental level: as we are perfectly aware, the fusion of the two peoples - by will of divine intervention - cannot be separated from the union of the two respective leaders.

In Book IV, indeed, the verb iungo (in the simple form as well as in its compounds adiungo and coniungo) ${ }^{1}$ appears variously declined in its multiple semantic values. It expresses the idea of the political fusion of the Carthaginians and the Trojans emerging from the conversation between Venus and Juno (... populos aut foedera iungi, 4, 112), which is ideally forseen in the union of their respective fellows led by Dido and Aeneas in the famous hunting scene (infert se socium Aeneas atque agmina iungit, "Aeneas himself, advances to join her and unites his band with hers", 4, 142). In its turn, this first 'merging' of the two groups seems to allude to the coniugium/conubium between Dido and Aeneas that will take place in the course of the hunting scene: conubio iungam stabili, "I will link them in sure wedlock", says luno $(4,126)$.

Through lexical spies, the space of narration itself also contributes to forsee this new private union. The evocation of the mountain ridges (iugum too is etimologically linked to iungo; 4,153 ) and the image of the blending of the natural elements (Interea magno misceri murmure caelum / incipit, insequitur commixta grandine nimbus, "Meanwhile in the sky begins the turmoil of a wild uproar; rain follows, mingled with hail", 4, 160-161) are an ideal forshadowing of the sexual fusion and the sexual intercourse of the two characters ${ }^{2}$.

Therefore, not only does Virgil use the verb iungo in reference to political alliances, but also with the meaning of joining people in marriage and, specifically, a wife to her husband: ...se pulchra viro dignetur iungere Dido, "in marriage fair Dido deigns to join herself", says the personified Fama $(4,192)^{3}$.

This sliding from Dido's first political project to the private motif of coniugium is also already implied in the amphibological use of the verb sociare, as emphasized by Servius in his comment on the expression urbe, domo socias $(1,600)$ : "Hoc est et publico et privato dignaris hospitio". In this case too, as with the verbs iungo and misceo, the term ranges from the bonds between peoples pertaining the public law to interpersonal relationships. To the political meaning ${ }^{4}$, therefore, Virgil steadily combines the marriage implications ${ }^{5}$, in the sense that marriage bond also represents the basis of societas ${ }^{6}$.

As is known, the cultural and political integration hoped by Dido will not occour. The Fate commands that Aeneas and the Trojans have to settle down in a new land. Et nos fas extera quaerere regna, "we, too, have the right to seek a foreign realm" $(4,350)$, states Aeneas, by implicitly underscoring the analogy between his personal story of exile to that of errans Dido, and thus anticipating the success of that union between other peoples from which Rome will originate. In the following books, Virgil will tell the migrations of the Trojans, their journey in search of a new homeland, and their impact on the

\footnotetext{
1 On the different meanings of iungo see Tibiletti Bruno 1987.

2 The verb misceo, after all, apart from indicating the fusion of the elements and metaphorically the merging of people in a group, alliance or association, also indicates the union by marriage as well as the sexual union in Virgil; see, for example, Verg. Aen. 7, 661 (mixta deo mulier). See Oxford Latin Dictionary, s.v. misceo, 4-5, p. 1116.

3 See Oxford Latin Dictionary, s.v. iungo, 7 "to unite or attach (persons) as friends, allies, or sim."; "to unite in marriage or sim.,": see Aen. 7, 546 (in amicitiam coeant et foedera iungant); Aen. 11, 128-129 (et te... Latino / iungemus regi); 4, 28-29 (ille meos, primus qui me sibi iunxit, amores / abstulit).

${ }^{4}$ The term socius, in its meaning of 'ally', recalls the juridical and political spheres and allows for the identification of a relationship legally limited by reciprocal obligations. These are relationships concerning international law, as they are meant to link the economical, political, and militaristic interests of single communities (Évrard - Pollera 1988, p. 913); in this regard see, for instance, Aen. 8, 120.

${ }^{5}$ The verb implies a reference to the marriage bond as it emerges from Aen. 4, 16 (vinclo... sociare iugali), in relation to which Servius comments as follows: "iugali autem propter iugum, quod imponebatur matrimonio coniungendis" (and Servius Danielinus: "quidam iugali accipiunt pro coniugali").

${ }^{6}$ The representation of the marriage bond in terms of societas is found in literature (illas tamen in matrimonio, in societate fortunarum omnium, Liv. 1, 9, 14; uxor est que foemina viro nuptiis collocata in societatem vitae venit, Quint. Declam. 247) but also in juridical texts (Dig. 25, 1, 2; Cod. 9, 32, 4). See Évrard - Pollera 1988.
} 
geopolitical reality of Ancient Italy, in the perspective of the future merging under the aegis of Gens lulia'. The whole Aeneid, after all, is the story of a man in search of a land and of the possibility, first ideal and then concrete, of a positive fusion between different Mediterranean cultures.

In conclusion, even if the integration proposed by Dido in Book I of Aeneid remains a mere possibility, its formulation is representative of an ancient cogitation about the importance of overcoming ethnic differences in order to build a fruitful dialogue between cultures and peoples. Like Arianna and Medea, Dido is one of the 'barbaric' princesses, eternalized by classical literature, who facilitated the creation of a European-Mediterranean identity².

In this light, the myth of Dido and Aeneas, in its archetypical aspects, still contributes to the current political reflection on the importance of a profound and fruitful intercultural dialogue, based on values such as equality, tolerance, the acceptance of diversity, and the centrality of the human being. It proves that we can still learn from our ancestors, and that it is always fruitful to go back to reinterpreting Virgil: as a matter of fact, every age and almost every generation has its new and peculiar questions to ask him.

\section{References:}

[1] Conte G.B. (2009). P. Vergilius Maro. Aeneis (rec.), Berlin: De Gruyter.

[2] De Martino F. - Degl'Innocenti Pierini R. (1985). Hospes, hospitium. In Enciclopedia Virgiliana II, Roma, pp. 859862.

[3] Évrard É. - Pollera A. (1988). Socius. In Enciclopedia Virgiliana IV, Roma: Istituto della Enciclopedia Italiana Treccani, pp. 912-915.

[4] Fiorentini M. (2003). Fiumi e mari nell'esperienza giuridica romana, Milano

[5] Fo A. (2012). Un profilo di Virgilio, in Publio Virgilio Marone. Eneide, Trad. a cura di A. Fo. Note di F. Giannotti. Torino: Giulio Einaudi editore, pp. VII-LXXXIII.

[6] Horsfall (1990): Dido in the light of History, in Harrison S.J., Oxford Readings in Vergil's Aeneid, Oxford: Oxford University Press.

[7] Iulietto M.N. (2014). Didone. Riscritture 'barocche' di un mito, Campobasso-Foggia: II Castello Edizioni.

[8] Iulietto M.N. (2015). Imagines Didonis. Prolegomeni allo studio di un mito, Umbertide (Perugia): University Book, Digital Editor.

[9] Lala R. (2006). 10.000 anni di identità europea, I. Torino: Alpina.

[10] Rushton Fairclough (1999). Virgil, Eclogues, Georgics, Aeneid I-VI, tr. H. Rushton Fairclough, revised by G. P. Goold, Cambridge, MA: Harvard University Press.

[11] Senis G. (1987). Misceo. In Enciclopedia Virgiliana III, Roma: Istituto della Enciclopedia Italiana Treccani, p. 541.

[12] Sini F. (2008). Persone e cose: res communes omnium, In "Diritto@Storia" 7.

[13] Stégen G. (1975). Le Livre I de l'Énéide. Namur: Maison d'éditions Ad. Wesmael- Charlier.

[14] Tibiletti Bruno M.G. (1987). Iungo. In Enciclopedia Virgiliana III, Roma: Istituto della Enciclopedia Italiana Treccani, pp. 63-64.

\footnotetext{
1 See Fo 2012, p. LV.

${ }^{2}$ Lala 2006, 43.
} 